IBAD Sosyal Bilimler Dergisi

IBAD Journal of Social Sciences

dergipark.org.tr/ibad

IBAD, 2022; (12): 137-163

DOI: $10.21733 /$ ibad. 948455

Özgün Araştırma / Original Article

\title{
The Effect of STEM and STEM-Based Robotics Activities on Constructive Learning
} Environments Opinions of Teacher Candidates

\section{STEM ve STEM Temelli Robotik Etkinliklerinin Öğretmen Adaylarının Yapılandırmacı Öğrenme Ortamları Görüşlerine Etkisi}

\author{
Hatice Çalik ${ }^{1^{*}}$ \\ Sema Altun Yalçın² \\ * Sorumlu yazar \\ Corresponding author
}

${ }^{1}$ Öğretmen, Milli Eğitim Bakanlığı, Türkiye,

Teacher, Ministry of Education, Turkey

hcalik03@gmail.com

ORCID ID https://orcid.org/0000-0003-3144-0984

${ }^{2}$ Prof. Dr. Sema Altun Yalçın, Erzincan Binali Yıldırım Üniversitesi, Türkiye,

Prof. Dr. Sema Altun Yalçın, Erzincan Binali Yıldırım University, Turkey,

sayalcin@erzincan.edu.tr

ORCID ID https://orcid.org/1013-0395-0110-0009

Makale geliş tarihi / First received : 05.06.2021

Makale kabul tarihi / Accepted : : 16.09.2021

\section{Bilgilendirme / Acknowledgement:}

\section{Yazarlar aşağıdaki billgillen dirmeleri yapmaktadırlar:}

1- Araştırmacıların katkı oranı eşittir.

2- Makale birinci yazarın ikinci yazar danışmanlı̆̆ındaki yüksek lisans tezinden türetilmiştir.

3- Makalenin yazarları arasında çıkar çatışması bulunmamaktadır.

4- Makalenin etik kurul izni Erzincan Binali Yıldırım Üniversitesi Rektörlüğü'nden 08/03 protokol numarası ile 07/08/2019 tarihinde alınmıştır.

5- Makaledeki deneysel çalışmalar, uluslararası deklerasyon, kılavuz vb.'ye uygun gerçekleştirilmiştir.

6- Bu makalede araştırma ve yayın etiğine uyulmuştur.

This article was checked by Turnitin. Similarity Index 15\%

\section{Atıf bilgisi / Citation:}

Çalik, H. \& Altun Yalçın, S., (2022). The Effect of STEM and STEM-Based Robotics Activities on Constructive Learning Environments Opinions of Teacher Candidates. IBAD Sosyal Bilimler Dergisi, (12), 137-163. 
ÖZ

$\mathrm{Bu}$ araştırmanın amacı fen bilgisi öğretmen adaylarında STEM ve STEM temelli robotik etkinliklerinin yapılandırmacı öğrenme ortamları görüşlerine etkisinin incelenmesidir. 2018-2019 akademik yllında gerçekleştirilen bu çalışmanın örneklemi Eğitim Fakültesi Fen Bilgisi Öğretmenliği Bölümünde öğrenim gören 31 öğretmen adayından oluşmaktadır. Araştırmada karma yöntem kullanılmıştır. Nicel verilerin toplanmasinda zayif deneysel desen kullanılmıştır. Araştırmada nicel verilerin toplanması amacıyla "yapılandırmacı öğrenme ortamı ölçeği" kullanılmıştır. Ayrıca nitel verilerin elde edilmesinde araştırmacı tarafından oluşturulan açık uçlu "yarı yapılandırmacı mülakat formu" kullanılmıştır. Nicel veriler paired sample t-testi, nitel veriler ise içerik analizi yöntemi kullanılmıştır. Araştırmada elde edilen bulgulara göre fen bilgisi öğretmen adaylarının STEM temelli robotik kodlama etkinliklerinin yapılandırmacı öğrenme ortamları görüşlerine etkisi öntest-sontest puanları karşılaştırıldığında anlamlı bir farklılık gösterdiği gözlemlenmiştir. Nitel verilere göre ise ögrretmen adayları STEM etkinliklerini yaparken olaylara bakış açıları, uyguladıkları yöntem-teknikler ile aldıkları sorumlulukların ve gerçek hayatla ilişkilendirmelerinde olumlu etki oluşturduğu gözlenmiştir.

\section{Anahtar kelimeler}

Robotik etkinlik, STEM, yapılandırmacı öğrenme.

\section{ABSTRACT}

The aim of this study is to examine the effects of STEM and STEM-based robotic activities on constructivist learning environments in pre-service science teachers. The sample of this study, which was conducted in the 2018-2019 academic year, consists of 31 teacher candidates studying at the Faculty of Education, Department of Science Education. Mixed method was used in the study. A weak experimental design was used in the collection of quantitative data. In the research, "Constructivist Learning Environment Scale" was used in order to collect quantitative data. In addition, an open-ended "semiconstructivist interview form" created by the researcher was used to obtain qualitative data. Quantitative data was paired sample t-test, qualitative data was used content analysis method. According to the findings obtained in the study, it was observed that the effect of STEM-based robotic coding activities of science teacher candidates on their views of constructivist learning environments showed a significant difference when their pretest-posttest scores were compared. According to the qualitative data, it was observed that while the teacher candidates were doing STEM activities, their perspective on the events, the responsibilities they took with the methods and techniques they applied, and their associations with real life were observed to have a positive effect.

\section{Keywords}

Robotic activity, STEM, constructivist learning. 


\section{INTRODUCTION}

With the rapid development of science and technology, which are the requirements of the age, it is essential to raise individuals who can keep up with this. Thus, science, society and technological applications of science are added to the objectives of science education curriculum (DeBoer, 2000, p. 583). It is expected to create a society foundation that produces solutions by using their knowledge in the face of the problems they encounter by raising science literate individuals who develop themselves technologically within the scope of the objectives. For this reason, with a multidisciplinary approach in education, it is aimed to consider one subject as the construction of another subject and even to create a link between the lessons (Wicklein \& Schell, 1995, p. 60). In order to achieve this, STEM integration has been used in education. In this way, by not keeping STEM separate from general education, the individual should be supported to specialize more and more at the advanced levels of education, starting from the primary school level (Xie, Fang \& Shauman, 2015, p. 347). STEM consists of the initials of the words science, technology, engineering and mathematics and each of these fields is defined as a holistic concept that intersects with other concepts (Ejiwal, 2013, p. 64). STEM education has a high effect on students' development of interdisciplinary knowledge and skills in different fields and in reorganizing their own ideas (Honey, Pearson \& Schweingruber, 2014, p. 23). One of the main objectives of STEM is to establish relationships between real life situations and academic disciplines and to use it in school, society, business and entrepreneurship, thus raising individuals with high competitive power and scientific creativity in the global economy (El-Deghaidy \& Mansour, 2015, p. 51). In order to achieve these goals, STEM education must be applicable in the curriculum. The need for qualified teachers in the field of STEM has increased in terms of applying STEM education and enabling students to acquire new skills, support creativity, innovativeness and entrepreneurship, and also create an opportunity for transition between professions by adapting to new professions (Thomas, 2014, p. 12). The concept of STEM was effective in science teaching plans in order to raise science literate individuals, to create a learning environment by living by doing and living for students who can think creatively and critically (Oner et al., 2016, p. 1). STEM education is an important factor in concretizing the subjects and increasing motivation in science teaching. At the same time, by adding mathematics, engineering and technology to science teaching, lessons can be made more interesting and enjoyable (Kennedy \& Odell, 2014, p. 254).

In the constructivist learning approach, it is based on the learner reviewing and interpreting previous knowledge by transferring it, not by memorizing it, and creating new knowledge (Pitsoe \& Maila, 2012, p. 6). In constructivist learning, the learner is not content with only his own knowledge, but provides active learning by interacting with his social environment (Cobern, 1996, p. 7). With constructivist learning, teachers contribute to the development of the cognitive aspect of the student by guiding the student to think, so that the student sees knowledge as a world to be discovered rather than a wall that is difficult to overcome. The duty of teachers is to organize the classroom environment in a way that motivates the student to learn and draws his attention to the subjects. In addition, the subject or fields in learning experiences are arranged according to the situation of the learner, not in a pre-determined state. These regulations are determined together with the teacher and the student (Aldridge et al., 2004, p. 245). The teacher develops knowledge, skills and attitudes suitable for 
constructivist learning and helps the child to structure his experiences in different areas. The student increases the permanence of learning with his interactions with his peers, taking into account the opinions of others as well as his own knowledge. First of all, the teacher should carefully organize the learning environment, create an atmosphere where children can freely express their ideas, ask questions, think and interact with their environment (Dharmadasa, 2000, p. 5).

Since the constructivist learning approach is suitable for engineering design processes, it allows to establish a relationship with daily life and emphasizes problem solving dimension, organizing a course suitable for STEM education is also a roadmap for the design of the education program. When the $5 \mathrm{E}$ model, which is one of the constructivist learning models, is used in STEM education, the student focuses on the subject, explores the information by researching it, organizes the obtained data and enables it to be transferred to new situations by learning in depth (Cepni, 2017, p. 206). STEM education, which is an interdisciplinary collaboration with a constructivist approach that puts the student at the center, creates an educational order that improves life skills by changing the individual's perspective on science (Seren \& Veli, 2018, p. 26). In addition, in these two approaches, it is desired to produce solutions to the problems faced by the individual in daily life, to think deeply and to gain the ability to think scientifically. Like the constructivist approach, STEM education is an understanding that puts the learner at the center and places emphasis on learning. It is stated that only cognitive skills are not sufficient for students' achievement while learning has a high effect on affective skills, therefore, increasing interest and motivation with STEM integration together with constructivist learning has a great contribution to learning (Cepni, 2017, p. 207).

When the literature is examined, it is seen that the constructivist learning approach also interprets the information that learners receive in the learning process and transfers them to different situations (Cobern, 1996, p. 3; Sasan, 2002; Nunes \& Pherson, 2003) and in this process, the student is always active so that problem solving skills develop (Hadjerrouit, 1998, p. 107; Katz, 1999, p. 16; Dharmadasa, 2000, p. 4; Qarareh, 2015, p. 181). It was observed that STEM activities centered on the 7E model, which is one of the ways of applying the constructivist learning approach, increased the grade average success of the students (Guven et al., 2018, p. 77). In the study, it is stated that the effect of STEM education and full learning model on the academic achievement of students and the retention of the learned information also on their motivation towards science (Yildırım \& Selvi, 2017, p. 203). Problem-based STEM education has positively affected students' feelings, thoughts and behaviors as an effect on their learning climate (Topsakal \& Altun Yalcin, 2020, p. 44). They stated that problem-based STEM education has a significant effect on students' learning, makes the lesson fun, increases their interest in the engineering profession, and improves their 21st century skills, thus making a positive effect on choosing their future careers (Alic1, 2018, p. 1). It has been stated that project-based STEM education has a positive effect on students' academic achievements and professional interests (Cevik, 2018, p. 293).

When the literature is examined, it is seen that the studies on the integration of four disciplines in the STEM approach and how the trainers will apply these programs are not sufficient (Dugger, 2010, p. 4). In addition, when the literature was examined, there was no study examining the effect of STEM education understanding on constructivist learning 
development with pre-service science teachers. In this study, the effects of STEM education given to pre-service teachers on the constructivist approach understanding of pre-service teachers were examined. With the development of constructivist approach, teachers create an interactive, refreshing and informative learning environment. In addition, the teacher who advocates the constructivist approach can make activities that are personal and original (Cobern, 1996, p. 10). Pre-service teachers who grew up in learning environments with a constructivist approach will be able to establish a meaningful relationship between theory and practice. Pre-service and in-service teachers' emphasis on constructivist approach reveals the idea that knowledge will be structured in the human mind and social environment with their experiences and it is stated that it can be used effectively in teacher education (Richardson, 1996, p. 103). The knowledge gained by the development of the constructivist approach in teacher candidates is used effectively and it is transformed into solution-oriented thinking and practice in problem situations (Bay and Karakaya, 2009, p. 41). In addition, the internalization of knowledge and the creation of an efficient learning environment with integrated programs play an important role in the development of teacher candidates (Aslan and Bektas, 2019, p. 19). Therefore, it is aimed to determine the effects of STEM and STEM-based robotics activities on the constructivist learning environments views of teacher candidates.

\section{METHOD}

Ethics committee approval was obtained from the Erzincan Binali Yildırım University Rectorate on 07/08/2019 with protocol number 08/03 for the research. In the study, mixed research method was used to support the effectiveness of the education whose effect was examined with evidence. With the mixed research method, the researcher uses different strategies, methods and approaches to better understand the research problem with quantitative and qualitative data (Baki and Gokcek, 2012, p. 2). In the study, the explanatory consecutive pattern, one of the mixed research methods was used. In the explanatory sequential design, firstly, quantitative data are collected, then the results of the quantitative analysis are examined and it is determined which questions to ask the participants at the qualitative stage. Qualitative data are collected and analyzed in order to explain the quantitative results in depth (Creswell, 2017, p. 39).

\section{Universe and Sample}

In the research, it was tried to reach the entire universe of the study. For this reason, the sample of the research consisted of all 4th grade teacher candidates studying at a state university of a medium-sized province of Eastern Anatolia, Faculty of Education, Department of Primary Education, Science Education Undergraduate Program in the 2018-2019 academic year. However, when the data collection tools were applied in the study, a total of 31 teacher candidates, 23 girls and 8 boys, were reached due to the fact that the students were not in the school.

\section{Limitations and Assumptions}

Limitations of the research; the application was carried out with 31 science teacher candidates who were studying in the 4th grade in the 2018-2019 academic year of the permissioned faculty. The data obtained from the Constructivist Learning Environments scales applied to the pre-service teachers were used. Within the scope of the application, STEM and STEM- 
based robotic activities were carried out with simple materials. In order to determine the feelings and thoughts about STEM activities, the data obtained from the reflective diaries applied after the activities were collected. It is limited to semi-structured interview data in which the opinions of 31 pre-service teachers studying in the 4th grade of science teaching department about constructivist learning were obtained.

As the assumptions of the research conducted; it is assumed that the pre-service teachers who participated in the research were sincere and impartial, whose opinions and suggestions were received about the applied activities and constructivist learning. It is assumed that the data collection tools used in the research are suitable for the research in line with the purpose of the research. In the research, it is assumed that pre-service science teachers have not received any previous training on STEM and STEM-based robotic activities. It is assumed that the experts consulted in the steps of designing and organizing the activities, preparing the data collection tools and analyzing the data are sincere in their views.

\section{Application Process}

Before the implementation process of the research started, the necessary research and literature review were made about the constructivist approach and STEM and STEM-based robotic activities that were desired to be measured in science teacher candidates. The study was conducted in the 2018-2019 academic year with 31 pre-service science teachers in the 4th grade within the scope of STEM and Robotics coding elective courses in a 14-week period.While conducting STEM Activities, the principles of the constructivist approach have been taken into account. The trainer only provided guidance, did not interfere with their learning experiences. The teacher candidates were given the necessary time to solve the problems they encountered themselves, and they were provided with the necessary researches and applications themselves. Informing the teacher candidates and pre-test and post-test applications are also included in this period. Before starting the study, the teacher candidates were interviewed with the researcher and the instructor of the lesson, and the teacher candidates were informed about the plan-program of the work to be carried out during the process. Before the implementation of the study, the first data were collected by applying the "constructivist learning environments" scales pre-tests to the pre-service teachers. Then, groups of 3-4 people were formed from teacher candidates. The distribution of tasks was determined by giving information about STEM and STEM-based robotic activities to the pre-service teachers, who could express their opinions in case of a problem and using the knowledge they had within the constructivist program, they would try different ways to solve the problem by using their creativity, and the weekly work to be done. The teacher candidates were made to have activities for 6 weeks with simple materials that they can easily find in their environment. Waddling robot, controlled snake, dancing giraffe, etc. activities were built. For 4 weeks, the coding of lego-style materials and thus the operation of the systems was ensured. For example, they have installed washing machines, dishwashers, carousels, sensor door systems with legostyle materials and enabled them to work by coding them. The pre-service teachers used the steps of the engineering design process during their studies. First, they identified the problem and searched for possible solutions to the problem. Afterwards, the most suitable solution was selected and the product was prototyped and the prototype was tested. It was stated that the application process was not sequential, and it was stated that the third step, the step of 
choosing the most suitable solution, could be returned to the beginning. Teacher candidates for 4 weeks; they were enabled to code with web 2.0 tools. For example; tinkercat, powtoon etc. tools were used.

In the process of STEM applications, the researcher acted as a guide. At the same time, the researcher was open to the opinions of prospective teachers and guided the development of study and creative thinking skills. The appropriateness of the STEM activities planned to be implemented was decided by asking the experts. Teacher candidates who did not have any knowledge and experience about STEM education participated in the event. In the application process, the volunteering of the teacher candidates was taken as a basis. STEM activities were preferred to be low in cost and easily available materials. With these activities, prospective teachers were given the opportunity to put the knowledge they have learned so far into practice with the integration of science, technology, engineering and mathematics. During the activities, instead of putting the teacher candidates in a certain pattern and creating the same product, support was given to create solutions to the problem and to design the most suitable product through consultation within the group. After the application, the constructivist learning environment scale was applied to the teacher candidates as a post-test and interviews were made at the end of the process in order to clarify the answers to the sub-problems. The questions in the interview were prepared by the researcher by considering each sub-problem and parallel to the items in the scale. These questions in the interview form were examined by experts in the field and finalized. With the semi-structured interview included in this study, it was aimed to determine the constructivist learning environments skills of prospective teachers in more detail and to reveal whether there was a change in these skills after the activity. The interview was conducted individually for each pre-service teacher for 15-25 minutes at a time when they were available.

\section{Data Collection Tools}

In this study, data collection tools related to both the research process and the evaluation process were used. Data collection tools and their intended use are explained below.

\section{Constructivist learning environments scale;}

Constructivist learning environment questionnaire, in which the language equivalence, validity and reliability of the Turkish form of the "Constructivist Learning Environment Scale" developed by Tenenbaum et al. (2001) in order to determine the views of prospective teachers on STEM-based robotic coding training activities on constructivist learning; relationship with real life, critical thinking, taking responsibility for learning, classroom language, assessment, physical environment, teacher role, method-technique and motivation.The reliability coefficient (cronbach alpha) of the questionnaire adapted by Bay (2008) was calculated as 0.85 . This questionnaire consists of a five-point likert and fifty-two (52) items. The survey is newly shaped by the purpose of the study in the doctoral thesis by Kaya (2010) and the survey. The relationship with real life, the right to critical thinking, physical medium, teacher role and teaching process-strategy method, are also composed of six sub-dimensions, and the number of substances is decreasing 32 items and five likerts. The reliability coefficient (Cronbach alpha) calculated by the researcher was found to be 0.984 . The sub-dimensions of the constructivist learning scale are reliability coefficient; the reliability coefficient of the relationship with real 
life sub-dimension was 0.741 ; the reliability coefficient of the right to critical thinking subdimension was 0.778 ; the reliability coefficient of the sub-dimension of taking responsibility for learning was 0.782; the reliability coefficient of the physical environment sub-dimension was 72 0.782; the reliability coefficient of the teacher role sub-dimension was 0.779; The reliability coefficient of the teaching process-strategy-method-technical sub-dimension was found to be 0.818 .

\section{Semi-structured interview form;}

With the interview forms, researchers try to explain the participants' interests, attitudes, values and concerns in more detail (Gay and Airasian, 2000). In this study, 6 questions were asked to determine the perceptions and opinions of STEM-based robotic activities regarding the constructivist learning approach before and after the activity. These questions were associated with the sub-dimensions of the constructivist learning environments scale. In interview questions regarding constructivist learning environments; "Do you think STEM education with simple materials is relevant to real life? How?" "Relationship to real life"; "Was there an environment where you can freely express your thoughts in STEM education with simple materials? Or does it create? " "The right to critical thought"; "Do you think STEM education with simple materials contributes to your learning life? Why is that? How?" "Taking responsibility for learning"; "What should be the physical environment in which STEM education will be done with simple materials? Why is that?" "Physical environment"; "What should the role of the teacher be in STEM education with simple materials? Why is that?" "Teacher role"; "What effect do you think STEM education with simple materials can have on students?" It is associated with the "teaching process-strategy method and technique" subdimension.

\section{Data Analysis Techniques}

Statistical method was used to analyze quantitative data in the study. SPSS 20.0 package program was used for the statistical method.

First of all, the "Kolmogorov-Smirnov" technique was used for the quantitative data obtained in the analysis. Kolmogorov-Smirnov test is a bit test that allows us to decide whether the data group shows normal distribution when the sample group is over 30. According to the test, when $p>0.05$, the data group is considered to have a normal distribution (Can, 2016, p. 81). Paired samples $t$ test, also known as "dependent sample $t$ test", was conducted to determine the difference between the pretest and posttest scores of the constructivist learning environments scale applied to the sample group.

Content analysis method was used to analyze qualitative data. In content analysis, the data that adorn each other are brought together around concepts and themes in order to be understood by the reader, and they are interpreted by making arrangements. It is one of the methods used to reveal different perspectives with the reflection of the designs applied by content analysis on the learning process (Miles and Huberman, 1994, p. 27). In the study, the qualitative data obtained from the semi-structured interview forms were analyzed with the method of content analysis, codes and categories for grouping these codes were determined. These codes and categories are shown in the tables below with their frequencies and percentages. 
Some applications have been made to ensure the validity of the applied qualitative data tools and analyzes. Eisner, (1991), Emden \& Sandelowski, (1998); In the studies conducted by Marshall (1990), reliability, originality and well-being were taken as validity criteria in qualitative research as appropriate criteria for the quality of qualitative research (Miles \& Huberman, 1984, p. 23). In addition, Maxwell developed five categories to evaluate the validity of qualitative research. These; descriptive validity, interpretive validity, theoretical validity, generalizability and evaluation validity. To ensure validity, the data must accurately reflect what the participants say and do, and must be reported accurately while reporting the data. The researcher's point of view should not be confused with the words, actions and comments of the participants, the concepts, categories and features should be compatible with the structures to be applied. At the same time, the fact that the participants give sincere and correct answers to the questions is effective in ensuring validity in qualitative research (Thomson, 2011, p. 79-80). Our qualitative validity measurement tool has been prepared in accordance with its items and purpose. By looking at the literature on the subject, a pool was created and presented to the experts in the field, and its final form was given.

In the content analysis performed to ensure the reliability of the qualitative measurement tools, the codes and categories determined independently of each other and without looking at the student names were compared with the researcher's own codes and categories in order to ensure impartiality by two different researchers. The reliability of the study was ensured by determining the number of consensus and disagreement. For this, the reliability coefficient was determined based on the formula (Reliability = Agreement / Agreement + Disagreement) developed by Miles and Huberman (1994) (Miles \& Huberman, 1994, p. 64). The reliability coefficient determined in this study was found to be $87 \%$ for semi-structured interview questions. Ozdamar (1999, p. 245) states that the scale is highly reliable when the criterion value of the reliability coefficient is $0.81<\mathrm{a}<1.00$. The codes that were in disagreement by the evaluators were re-evaluated together.

\section{RESULTS}

In this section, the quantitative and qualitative data obtained from the research were analyzed according to the sub-problems and the findings obtained were presented.

\section{Findings and Comments about Constructivist Learning Environments}

In order to determine whether there is a significant difference between the pre-test and posttest scores of the sample group in which STEM and STEM-based robotics activities were applied in the sub-problem, paired samples t-test was performed on the data obtained with the constructivist learning environment scale, and the results are below Table 1 is given. It is included in 1. In the paired samples t-test, pre and post test averages are compared on the same sample group (Can, 2016, p. 136). In the study, the differences between the pre and post tests of education on a single group on the dependent variable constructivist learning were examined. Before looking at the $\mathrm{T}$ test, it was observed that the data obtained with the constructivist learning tendencies scale showed a normal distribution and it was observed that the total scores provided homogeneity ( $p>0.05$; Can, 2016, p. 81). With the Kolmogorov Sminov test, the pretest kurtosis value of the scale was -.662 , the skewness value was 0.850 , the posttest kurtosis value was -.451, the skewness value was -.805. According to George \& 
Mallery (2010), "a kurtosis value of \pm 1.0 is considered excellent for most psychometric purposes, but a value of \pm 2.0 is also acceptable in most situations, depending on the particular application."

In the sub-problem, paired samples t-test was applied to the data obtained with the Constructivist Learning Environment Scale, which was used to determine whether there was a significant difference between the pre-test and post-test scores in terms of the effect of STEM and STEM-based robotic activities on the views of constructivist learning environments of the sample group. The results are given in Table 1 below.

Table 1.

\begin{tabular}{|c|c|c|c|c|c|c|c|}
\hline & Measurements & $\mathrm{N}$ & $\bar{X}$ & Ss & $\mathrm{t}$ & $\mathrm{Sd}$ & $\mathrm{p}$ \\
\hline \multirow{2}{*}{ Total } & pretest & 28 & 111,21 & 12,94 & \multirow{2}{*}{$-10,256$} & \multirow{2}{*}{27} & \multirow{2}{*}{,000 } \\
\hline & posttest & 28 & 140,21 & 13,63 & & & \\
\hline \multirow{2}{*}{$\begin{array}{l}\text { Relationship with real } \\
\text { life }\end{array}$} & pretest & 24 & 18,2 & 1,97 & \multirow[b]{2}{*}{$-6,313$} & \multirow[b]{2}{*}{23} & \multirow[b]{2}{*}{, 000} \\
\hline & posttest & 24 & 21,79 & 2,55 & & & \\
\hline \multirow{2}{*}{ Critical thinking } & pretest & 27 & 17,37 & 2,18 & \multirow[b]{2}{*}{$-6,789$} & \multirow[b]{2}{*}{26} & \multirow[b]{2}{*}{, 000} \\
\hline & posttest & 27 & 21,55 & 2,62 & & & \\
\hline \multirow{2}{*}{$\begin{array}{l}\text { Taking responsibility } \\
\text { for learning }\end{array}$} & pretest & 14 & 28,64 & 3,47 & \multirow{2}{*}{$-7,128$} & \multirow{2}{*}{13} & \multirow{2}{*}{,000 } \\
\hline & posttest & 14 & 36,14 & 3,43 & & & \\
\hline \multirow{2}{*}{ Physical environment } & pretest & 26 & 17,76 & 3,32 & \multirow{2}{*}{$-7,544$} & \multirow{2}{*}{25} & \multirow{2}{*}{,000 } \\
\hline & posttest & 26 & 22,92 & 2,29 & & & \\
\hline \multirow{2}{*}{ Teacher role } & pretest & 27 & 18,03 & 2,99 & \multirow{2}{*}{$-6,881$} & \multirow{2}{*}{26} & \multirow{2}{*}{,000 } \\
\hline & posttest & 27 & 22,55 & 2,42 & & & \\
\hline Teaching process- & pretest & 28 & 13,53 & 2,99 & \multirow[b]{2}{*}{$-8,136$} & \multirow[b]{2}{*}{27} & \multirow[b]{2}{*}{,000 } \\
\hline $\begin{array}{l}\text { Strategy method } \\
\text { technique }\end{array}$ & posttest & 28 & 18,39 & 2,42 & & & \\
\hline
\end{tabular}

$\mathrm{P}<0,05$

Paired samples t-test results made between pre-test and post-test scores of pre-service teachers' perceptions of constructivist learning environments are shown in Table 1. Paired samples t-test was conducted to determine the effects of the activities on pre-service teachers' perceptions of constructivist learning environments. In the results of the test, a statistically significant difference was found between the mean score before the application $\left(\bar{X}_{\text {pretest }}=\right.$ 111.21) and the average score after the application $\left(\bar{X}_{\text {posttest }}=140.21\right)\left(t_{49}:-6.313, p<0.05\right.$; Can, 2016, p. 136). Paired samples t-test was conducted to determine the significant difference between pre-test and post-test scores of the "relationship with real life" sub-dimension of the effect of activities on the constructivist learning environment of pre-service teachers in the sub-dimension analysis of the constructivist learning environment "relationship with real life" of prospective teachers. In the results of the test, a significant difference was observed between the mean score before the application $\left(\bar{X}_{\text {pretest }}=18.2\right)$ and the mean score after the 
application $\left(\bar{X}_{\text {posttest }}=21.79\right)\left(\mathrm{t}_{49}:-6.313, \mathrm{p}: 0.00\right),(\mathrm{p}<0.05$; Can, 2016, p. 136). Paired samples $\mathrm{t}-$ test was conducted in order to determine the significant difference between pre-test and post-test scores of the "right to critical thinking" sub-dimension of the effect of activities on the constructivist learning environment of pre-service teachers in the "right to critical thinking" sub-dimension analysis of pre-service teachers' constructive learning environment. In the results of the test, a significant difference was observed between the mean score before the application $\left(\bar{X}_{\text {pretest }}=17.37\right)$ and the mean score after the application $\left(\bar{X}_{\text {posttest }}=21.55\right)\left(\mathrm{t}_{49}\right.$ : 6.798, p: 0.00), ( $<<0.05$; Can, 2016, p. 136). Paired samples t-test was conducted to determine the significant difference between the pre-test and post-test scores of the "taking responsibility for learning" sub-dimension of the effect of activities on the constructivist learning environment of pre-service teachers in the sub-dimension analysis of the constructivist learning environment of the teachers. In the results of the test, a significant difference was observed between the mean score before the application $\left(\bar{X}_{\text {pretest }}=28.64\right.$ ) and the mean score after the application $\left(\bar{X}_{\text {posttest }}=36.14\right)\left(\mathrm{t}_{49}\right.$ : $\left.-7.128, \mathrm{p}: 0.00\right),(\mathrm{p}<0.05$; Can, 2016, $\mathrm{p}$. 136). Paired samples t-test was conducted to determine the significant difference between pre-test and post-test scores of the "physical environment" sub-dimension of the effect of teacher candidates' constructivist learning environment "physical environment" activities on the constructivist learning environment of pre-service teachers. In the results of the test, a significant difference was observed between the mean score before the application $\left(\bar{X}_{\text {pretest }}=\right.$ 17.76) and the mean score after the application $\left(\bar{X}_{\text {posttest }}=22.92\right)\left(\mathrm{t}_{49}:-7.544, \mathrm{p}: 0.00\right),(\mathrm{p}<0.05$; Can, 2016, p. 136). Paired samples t-test was conducted to determine the significant difference between the pre-test and post-test scores of the "teacher role" sub-dimension of the effect of activities on the constructivist learning environment of pre-service teachers in the "teacher role" sub-dimension analysis of pre-service teachers. In the results of the test, there was a significant difference between the mean score before the application $\left(\bar{X}_{\text {pretest }}=18.03\right)$ and the mean score after the application $\left(\bar{X}_{\text {posttest }}=22.55\right)\left(t_{49}:-6.881, p: 0.00\right),(p<0.05$; Can, 2016, p. 136). Paired samples t-test was conducted to determine the significant difference between pre-test and post-test scores of the "teaching process-strategy method technique" sub-dimension of the effect of activities on the constructivist learning environment of preservice teachers in the "teaching process-strategy method technique" sub-dimension analysis of the pre-service teachers' constructivist learning environment. In the results of the test, a significant difference was observed between the mean score before the application $\left(\bar{X}_{\text {pretest }}=\right.$ 13.53) and the mean score after the application $\left(\bar{X}_{\text {posttest }}=18.39\right)\left(\mathrm{t}_{49}:-8.136, \mathrm{p}: 0.00\right),(\mathrm{p}<0.05$; Can, 2016, p. 136).

\section{Findings of Qualitative Data}

Qualitative content analyzes of each question prepared in order to get the views of the sample group in which STEM and STEM-based robotics activities were applied and to observe what kind of effects it had on this education, were made and the tables and comments of the content analyzes made for each question are given below. 
Table 2. Relation of STEM activities with real life, before the activity

\begin{tabular}{lllll}
\hline Category & Code name & Frequency (F) & Percent (\%) \\
\hline \multirow{4}{*}{ Attitude } & I didn't know & 5 & $11,63 \%$ \\
& Narrow perspective & 1 & $2,33 \%$ \\
& Contents & 1 & $2,33 \%$ \\
\cline { 3 - 5 } Pre & Real life & 29 & $67,44 \%$ \\
& \multirow{4}{*}{ Thoughts on Education } & 4 & $9,30 \%$ \\
& & Technology & & $2,33 \%$ \\
& & Associated with the engineering & $2,33 \%$ \\
& & field & 1 & $2,33 \%$ \\
\hline & I couldn't reconcile & 1 & $100,00 \%$ \\
\hline
\end{tabular}

Table 2 before the activity "Do you think STEM education with simple materials is related to real life? How?" The answers of the teacher candidates regarding the question were included. When the answers are examined; a total of 2 categories emerge: attitude and thoughts about education. In the attitude category; the pre-service teachers stated that they were not aware of STEM education and some pre-service teachers had no idea and did not know the content. It was stated that they looked at with a narrow perspective before getting training. In the category of thoughts about education; in this category, pre-service teachers stated that the activities they do in STEM education are related to real life, it is necessary to keep up with the developing technology, it is connected with the engineering field, technology is simple and less complex. Some preservice teachers stated that they did not think it was related to daily life and could not associate it with daily life events before receiving the training.

"Do you think STEM education with simple materials is relevant to real life? How?" The opinions of the teacher candidates regarding the question are given below.

S1: "Before taking the STEM lesson, I thought that many of the projects we made using simple materials would not be of any use in real life. In fact, the projects they did seemed very simple to me, so I could not associate it with real life."

Table 3. Relation of STEM activities with real life, after the activity

\begin{tabular}{|c|c|c|c|c|}
\hline & Category & Code name & Frequency $(\mathrm{F})$ & Percent $(\%)$ \\
\hline \multirow{12}{*}{ Post } & \multirow{7}{*}{$\begin{array}{l}\text { In terms of Contribution } \\
\text { to Daily Life }\end{array}$} & Learning code & 5 & $10,64 \%$ \\
\hline & & Working principle & & \\
\hline & & materials & 4 & $8,51 \%$ \\
\hline & & Solution to the problem & 4 & $8,51 \%$ \\
\hline & & Detecting & & \\
\hline & & beforehand & 3 & $6,38 \%$ \\
\hline & & Make a project & 1 & $2,13 \%$ \\
\hline & \multirow{5}{*}{ Learning } & Concrete learning & 1 & $2,13 \%$ \\
\hline & & Permanent learning & 1 & $2,13 \%$ \\
\hline & & Application oriented & 1 & $2,13 \%$ \\
\hline & & Interdisciplinary & 1 & $2,13 \%$ \\
\hline & & Wide view & 1 & $2,13 \%$ \\
\hline
\end{tabular}




\begin{tabular}{clll} 
& About real life & 18 & $38,30 \%$ \\
& Simple and small things & 3 & $6,38 \%$ \\
Idea & Do it effortlessly & 2 & $4,26 \%$ \\
& I can fix & 1 & $2,13 \%$ \\
& Making learning easier & 1 & $2,13 \%$ \\
\hline Total & & 47 & $100,00 \%$ \\
\hline
\end{tabular}

After the activity "Do you think STEM education with simple materials is related to real life? How?" The answers of the teacher candidates regarding the question were included. When the answers are examined; in terms of contribution to daily life, a total of 3 categories emerge as learning and thinking. In its category in terms of contribution to daily life; the pre-service teachers stated that they can produce solutions in the face of the problems they encounter, determine the problems that may occur in advance and make projects. Another contribution of the activities to daily life was stated as learning the codes of electronic devices and understanding the working principles of these devices. In the learning category; the teacher candidates stated that their activities were concrete learning, permanent learning, establishing interdisciplinary bonds and the work done was oriented towards practice. He also stated that he got rid of the narrow gaze and enabled to look at events from a broad perspective. In the category of thought; the preservice teachers stated that the STEM education they received was related to real life, and that if you want to produce something, you should start with simple and small things first. They stated that the idea that I can fix the broken things after the activities occurred, it facilitated learning and created the idea of how I can do it without difficulty.

"Do you think STEM education with simple materials is relevant to real life? How?" The opinions of the teacher candidates regarding the question are given below

S1: "... we establish connections with cables while making a walking robot. I think we can compare this to many products that we encounter in daily life. That's why I can say that it makes more sense to me when I relate to real life ..."

Table 4. The effect of STEM activities on expressing thoughts freely, before the activity

\begin{tabular}{lllll}
\hline & & & \multicolumn{2}{l}{ Frequency } \\
$($ Category & Code name & $(\mathrm{F})$ & Percent (\%) \\
\hline \multirow{3}{*}{ Pre } & Ettitude & Environment & 28 & $62,22 \%$ \\
& & Idea & 9 & $20,00 \%$ \\
\cline { 3 - 5 } & \multirow{2}{*}{ Idea } & Claim & 1 & $2,22 \%$ \\
\hline & Interaction & 5 & $11,11 \%$ \\
& Total & Work & 2 & $4,44 \%$ \\
\hline
\end{tabular}

Table 4 before the activity "Was there an environment where you can freely express your thoughts in STEM education with simple materials? Or does it create?" The answers of the teacher candidates regarding the question were included. When the answers are examined; a total of 2 categories emerge, namely attitude and thought. In the attitude category; in this category, the preservice teachers stated that in STEM education, an environment where they 
can express their thoughts freely will not be created, and they can avoid producing ideas. They stated that they did not have any idea about STEM and did not want to take the lesson. Some preservice teachers stated that an environment in which they can freely express their thoughts will be created in education. In the category of thought; the preservice teachers stated that oneto-one interaction could not be established in this category due to the crowded classroom environment, no one could express their opinion and there would be discussions. Some teacher candidates stated that they think that there will be an intense work environment and that everyone will do the same things.

"Has there been an environment where you can freely express your thoughts in STEM education with simple materials? or does it create?" The opinions of the teacher candidates regarding the question are given below.

S1: "Before taking this training, I used to think that our thoughts would not be expressed freely. So I hesitated a little while taking this course That's why I didn't want to take this lesson first."

Table 5. The effect of STEM activities on expressing thoughts freely, after the activity

\begin{tabular}{|c|c|c|c|c|c|}
\hline & Category & & Code name & $\begin{array}{l}\text { Frequency } \\
\text { (F) }\end{array}$ & Percent (\%) \\
\hline \multirow{10}{*}{ Post } & \multirow{4}{*}{\multicolumn{2}{|c|}{ Attitude }} & Self-sufficiency & 6 & $9,23 \%$ \\
\hline & & & Funny & 2 & $3,08 \%$ \\
\hline & & & I love the environment & 1 & $1,54 \%$ \\
\hline & & & Imagination & 1 & $1,54 \%$ \\
\hline & \multirow{4}{*}{$\begin{array}{l}\text { Method } \\
\text { Technique }\end{array}$} & \multirow{4}{*}{ and } & Project & 5 & $7,69 \%$ \\
\hline & & & Brainstorming & 4 & $6,15 \%$ \\
\hline & & & Creativity & 3 & $4,62 \%$ \\
\hline & & & Living by doing & 1 & $1,54 \%$ \\
\hline & \multirow{2}{*}{ Sociability } & & Being able to express & 29 & $44,62 \%$ \\
\hline & & & Team work & 13 & $20,00 \%$ \\
\hline & Total & & & 65 & $100,00 \%$ \\
\hline
\end{tabular}

After the activity, "Was there an environment where you can freely express your thoughts in STEM education with simple materials? Or does it create?" The answers of the teacher candidates regarding the question were included. When the answers are examined; three categories emerge: attitude, method and technique, and sociability. The teacher candidates stated that they love the environment after the activities, it gives a feeling of courage and selfconfidence, improves self-confidence, self-efficacy and improves imagination, and the education is fun and enjoyable. In the category of method and technique; the teacher candidates stated that they learn by living by doing with the education they received, develop their creativity, try different ways with brainstorming, and combine different ideas in the same line where their power of interpretation and skills develop, sometimes they produce common ideas and put forward projects. In the category of sociability; the preservice teachers stated that they can express their thoughts freely by doing group work with STEM education, that ideas are valued, they exchange ideas as level discussions and respect each other's ideas within the group, thus they develop socially. Some preservice teachers stated that they could express their 
thoughts more easily with small groups or individually, and some preservice teachers stated that an environment where they could express their thoughts freely was not created.

"Has there been an environment where you can freely express your thoughts in STEM education with simple materials? Or does it create? " The opinions of the teacher candidates regarding the question are given below.

S1: "Yes, it was created because we made most of the products we designed and created as a group. We were constantly brainstorming and having a level discussion within the group. Everyone could freely say what they wanted to have their own opinion while creating the product."

Table 6. Effect of STEM activities on new knowledge, before the activity

\begin{tabular}{|c|c|c|c|c|}
\hline & Category & Code name & $\begin{array}{l}\text { Frequency } \\
\text { (F) }\end{array}$ & Percent (\%) \\
\hline \multirow{8}{*}{ Pre } & \multirow{4}{*}{ Yes } & New knowledge & 18 & $43,90 \%$ \\
\hline & & I learned the benefits & 3 & $7,32 \%$ \\
\hline & & Wonder & 1 & $2,44 \%$ \\
\hline & & Trial and error & 1 & $2,44 \%$ \\
\hline & \multirow{4}{*}{ No } & Information & 12 & $29,27 \%$ \\
\hline & & Beneficial & 4 & $9,76 \%$ \\
\hline & & Lego & 1 & $2,44 \%$ \\
\hline & & Free environment & 1 & $2,44 \%$ \\
\hline & Total & & 41 & $100,00 \%$ \\
\hline
\end{tabular}

Table 6 before the activity "Did you get new information during STEM education with simple materials? How?" The answers of the teacher candidates regarding the question were included. When the answers are examined; there are two categories: acquiring knowledge and acquiring knowledge. It is stated whether teacher candidates can acquire new sages with the education they will receive in this category. The pre-service teachers stated that before the STEM education they will receive, each project is new information, they are curious about the course, and it is thought that new information will be acquired. Some preservice teachers stated that they gained different knowledge and experience through trial and error, and that they learned about the course and its benefits. The pre-service teachers stated that they did not know about education before taking STEM education, they did not think that they would acquire new information, they did not know that it was useful and useful. In addition, they stated that they have limited knowledge as STEM education is only with Legos. They stated that they do not think that learning environments are not free and that they are a lesson open to learning.

"Did you get new information during STEM education with simple materials? How?" The opinions of the teacher candidates regarding the question are given below.

S1: "Before I get training, do I want to say that he doesn't know that he is so useful, helpful and open to learning ..."

Table 7. Effect of STEM activities on new knowledge, after the activity

\begin{tabular}{cccc}
\hline Category & Code name & Frequency & Percent $(\%)$ \\
\hline
\end{tabular}




\begin{tabular}{|c|c|c|c|c|c|}
\hline & & & & $(\mathrm{F})$ & \\
\hline \multirow{10}{*}{ Post } & \multirow{4}{*}{\multicolumn{2}{|c|}{ Learning }} & New knowledge & 18 & $36,00 \%$ \\
\hline & & & Clutch & 8 & $16,00 \%$ \\
\hline & & & New skill & 3 & $6,00 \%$ \\
\hline & & & Alternative & 3 & $6,00 \%$ \\
\hline & \multirow{3}{*}{\multicolumn{2}{|c|}{$\begin{array}{l}\text { Method } \\
\text { Technique }\end{array}$}} & $\begin{array}{l}\text { Learning by doing and } \\
\text { experiencing }\end{array}$ & 7 & $14,00 \%$ \\
\hline & & & Problem solving & 2 & $4,00 \%$ \\
\hline & & & Information exchange & 2 & $4,00 \%$ \\
\hline & \multirow{3}{*}{ Attitude } & & Motivating & 3 & $6,00 \%$ \\
\hline & & & Funny & 2 & $4,00 \%$ \\
\hline & & & Permanent & 2 & $4,00 \%$ \\
\hline & Total & & & 50 & $100,00 \%$ \\
\hline
\end{tabular}

After the activity "Did you get new information during STEM education with simple materials? How?" The answers of the teacher candidates regarding the question were included. When the answers are examined; a total of 3 categories emerge: learning, method and technique, and attitude. The teacher candidates stated that they used the knowledge they gained in this category in different dimensions, gained new solutions, knowledge and skills, and reconciled robotic coding with science lesson. They also stated that they learned about connecting the motor to the battery, coding, using alternative materials instead of non-existent materials, the working mechanism of the tools and what the materials do. In the category of method and technique; the teacher candidates stated that their problem-solving skills developed by doing activities and learning by experiencing, contributed to the interpretation, they put them into practice by using their previous knowledge and doing research, thus improving their psychomotor skills. At the same time, they stated that they embody what they have learned, provide creative thinking and produce projects through information exchange. In the attitude category; pre-service teachers stated that STEM education is entertaining, motivating and happy. In addition, they stated that permanent learning was provided with this training and that what they did with the desire to produce without memorization improved themselves.

"Did you get new information during STEM education with simple materials? How?" The opinions of the teacher candidates regarding the question are given below.

S1: "The newest knowledge I learned in STEM education, I got the idea that everything that seems difficult with a motor battery and a key can be accomplished step by step, with patience and curiosity, with a little effort."

Table 8. Physical environment in STEM activities

\begin{tabular}{llll}
\hline Category & Code name & Frequency (F) & Percent (\%) \\
\hline \multirow{2}{*}{ Physical } & Spacious & 29 & $34,12 \%$ \\
Environment & Quantity & 25 & $29,41 \%$ \\
& Useful & 12 & $14,12 \%$ \\
\hline
\end{tabular}




\begin{tabular}{llll} 
& Comfortable & 6 & $7,06 \%$ \\
& Safe & 2 & $2,35 \%$ \\
\hline \multirow{2}{*}{ Sensory } & Information exchange & 7 & $8,24 \%$ \\
Environment & Away from the noise & 3 & $3,53 \%$ \\
& Controlled & 1 & $1,18 \%$ \\
\hline Total & & 85 & $100,00 \%$ \\
\hline
\end{tabular}

Table 8 "What should be the physical environment in which STEM education will be carried out with simple materials? Why is that?" The answers of the teacher candidates regarding the question were included. When the answers are examined; a total of 2 categories emerge, namely physical environment and sensory environment. The teacher candidates stated that the environment in which the education will be taken in this category should be spacious, bright, wide and clean. In addition, it was stated that the materials should be in order, all the necessary materials should be found, safety measures should be taken, the number of sockets should be sufficient and high, economical materials should be used, panels should be hung on the walls, and the groups should not be crowded and large tables should be used to make the work more comfortable.

In the sensory environment category; In this category, the teacher candidates stated that the educational environment should be a controlled environment away from noise, where ideas are valued and freely expressed, information is exchanged, students can see each other and communicate.

"What should be the physical environment in which STEM education will be done with simple materials? Why is that?" The opinions of the teacher candidates regarding the question are given below.

S1: "There should be an environment where the materials can stay tidy, there should be a classroom environment with all materials and most importantly, it should be a place where security measures are at the highest level because the materials we use are dangerous."

Table 9. Teacher role in STEM activities

\begin{tabular}{llll}
\hline Category & Code name & Frequency (F) & Percent (\%) \\
\hline \multirow{3}{*}{ Teacher Features } & Knowledgeable & 4 & $5,97 \%$ \\
& Innovator & 4 & $5,97 \%$ \\
& Should enjoy & 2 & $2,99 \%$ \\
& Patient & 1 & $1,49 \%$ \\
\hline \multirow{2}{*}{ Teacher Role } & Guide & 33 & $49,25 \%$ \\
& Helper & 16 & $23,88 \%$ \\
\hline \multirow{2}{*}{ Total } & Motivated & 4 & $5,97 \%$ \\
\hline
\end{tabular}

Table 9 "What should be the role of the teacher in STEM education with simple materials? Why is that?" The answers of the teacher candidates regarding the question were included. When the answers are examined; a total of 2 categories emerge, namely, teacher characteristics 
and teacher role. The preservice teachers stated that in STEM education, the teacher should enjoy the activity, be patient with the students, and be forward-looking. In addition, they stated that the teacher should have the necessary knowledge and skills, should be able to give education to the students wholeheartedly, be creative, innovative and use their imagination. In the category of teacher characteristics; it was stated that the teacher should guide the students, inform them, guide them, provide their help, offer opportunities, and be equal to everyone. In addition, it was stated that the passive student should be active in these studies, providing useful materials, providing motivation by showing and making the studies by showing them with daily life.

"What should the role of the teacher be in STEM education with simple materials? Why is that?" The opinions of the teacher candidates regarding the question are given below.

S1: "The teacher should plan and know everything in advance for the robots to be built and made. The teacher should guide the students He should guide and assist them in matters that they cannot do. The teacher should be innovative and should always come to education with different ideas."

Table 10. Effects of STEM activities on students

\begin{tabular}{llll}
\hline Category & Code name & Frequency $(\mathrm{F})$ & Percent (\%) \\
\hline \multirow{3}{*}{ Attitude } & Interesting & 5 & $5,56 \%$ \\
& Self-confidence & 4 & $4,44 \%$ \\
& Solidarity & 2 & $2,22 \%$ \\
\hline \multirow{3}{*}{ Idea } & Educational and tutorial & 6 & $6,67 \%$ \\
& Helpful & 6 & $6,67 \%$ \\
& Memorable & 4 & $4,44 \%$ \\
Feeling & Innovator & 1 & $1,11 \%$ \\
& Funny & 6 & $6,67 \%$ \\
& Curious & 6 & $6,67 \%$ \\
\multirow{3}{*}{ Skill } & Responsibility & 1 & $1,11 \%$ \\
\hline \multirow{2}{*}{ Individual } & Hand dexterity & 9 & $10,00 \%$ \\
competence & Self-improvement & 4 & $4,44 \%$ \\
& Perspective & 3 & $3,33 \%$ \\
\hline \multirow{3}{*}{ Method } & Productive & 3 & $3,33 \%$ \\
Technique & Multi-faceted look & 2 & $2,22 \%$ \\
& Reconciliation & 2 & $2,22 \%$ \\
\hline Total & Questioning & 10 & $11,11 \%$ \\
\hline \multirow{2}{*}{ and } & Problem solving & 6 & $6,67 \%$ \\
& Creativity & 5 & $5,56 \%$ \\
& Constructivist thinking & 3 & $3,33 \%$ \\
& Living by doing & 2 & $2,22 \%$ \\
\hline & & 90 & $100,00 \%$ \\
\hline
\end{tabular}

Table 10 "What effect do you think STEM education with simple materials can have on students?" The answers of the teacher candidates regarding the question were included. In the attitude category; here, students' attitudes towards STEM education are included. The candidates stated that the activities had thought-provoking aspects that would positively affect 
the self-confidence and self-efficacy of the students. In the activities, they stated that they are insistent in the face of problems and not giving up can be carried out with solidarity and cooperation. In the category of thought; in this category, the candidates were guided by the effects of the activities on the students in terms of thinking. The preservice teachers stated that with the implementation of STEM education, the information acquired by the students will be permanent and include educational and instructive activities that they can use in daily life, and that they can be effective and useful studies that guide innovative thinking that enhances imagination. In the category of emotion; the preservice teachers stated that students will find the activities fun in this category, their curiosity will increase, their sense of responsibility will increase both in group work and individual work, and they will love the lesson thanks to the activities. In the skill category; the candidates stated that STEM activities will improve students' manual skills, establish relationships between events and create new products, understand the working mechanism of existing technological devices, and also produce solutions to problems in a short time and achieve success in different areas, which will positively affect their personal development. In the individual competence category; the teacher candidates stated that training in this category leads students to productivity, by looking at events in a versatile way, making associations between subjects while in the lesson and producing products using the materials they have in this process, as well as discovering new inventions in this process, as well as enabling them to learn easily. In the category of method and technique; the preservice teachers stated that STEM education will improve students' problem-solving skills by doing research and examination in the face of problems. At the same time, they stated that by questioning that they could progress by thinking, constructivist thinking skills would be developed and improvements would be achieved in analyzing events.

"What effect do you think STEM education with simple materials can have on students?" Some of the preservice teachers' opinions regarding the question are given below.

S1: "... helps them understand the relationship between events better It enables them to find solutions to the problems they encounter in a shorter time. It improves self-confidence and self-efficacy. It encourages students to think with flexibility and confidence. It provides design-oriented and innovative thinking."

\section{DISCUSSION}

In line with the findings obtained as a result of the studies carried out to measure the effect of STEM and STEM-based robotic activities on the constructivist learning environments views of pre-service science teachers, when the quantitative and qualitative analyzes are considered together, it has been concluded that there is an increase in favor of the posttest and this increase is at a significant rate. Based on the result obtained from the quantitative data in the study, the STEM activities applied within the scope of the study affected the constructivist learning environments and significantly contributed to all and sub-dimensions of the constructivist learning environments, and according to the results obtained from the qualitative data, the relationship of the activities with real life, the right to critical thinking, and the responsibility to learn. recruitment, physical environment, the role of the teacher, and the teaching process-strategy method and technique. 
Guldemir and Cinar (2017) examined the views of science teachers and middle school students on STEM activities. As a result of the study, most of the students expressed a positive opinion about the use of the STEM approach in lessons, and it was stated that the science course is not a discipline by itself, but will improve students' skills by associating it with other disciplines. There has been an increase in favor of posttest in quantitative analysis of critical thinking right and physical environment sub-dimensions. In the study, it was stated that pre-service teachers could express their thoughts freely with critical thinking, and thus learning was memorable. It was stated that critical thinking and evaluation among peers with a constructivist approach have a positive contribution to learning (Leask and Younie, 2001, p. 126). According to Nunes and Pherson (2003), it is stated that in higher education, the student should be critical in his / her view of events, and it is easier to learn knowledge and concepts by communicating comfortably in this process. In the 2020 studies of Cakır et al., it was stated that STEM activities based on the Montessori approach showed a positive development in the critical and highlevel thinking skills of preschool teachers.

In this study, according to the preservice teachers' responses to the instructor and to express their thoughts in the group; While the teacher candidates thought that they would not be able to express their thoughts comfortably before the activity, this rate increased in the opposite direction in the interview held after the activity. The quantitative and qualitative analysis results of the critical thinking right and physical environment sub-dimensions support each other. The preservice teachers stated why they learned the information they learned in the lessons or their thoughts about the method and techniques they used, and that they could express themselves easily when they did not understand. In this case, it can be said that educators provide prospective teachers with an environment where they can express their thoughts freely. They stated that they can make arrangements as they want when necessary, since learning environments increase the effectiveness of learning in terms of interacting and being able to do studies easily. In the qualitative analyzes of the study, it was stated that preservice teachers might be hesitant in generating ideas in the lessons, and therefore they do not think that anyone can express their thoughts freely due to the busy working environment, and that they can express their thoughts freely in group work and in their communication with their trainers in post-event interviews, they are at a common point from level discussion environments by producing different ideas. They stated that unification is possible. It can be said that this situation contributes to the fact that teacher candidates dare to express their thoughts in activity environments and that they can express themselves freely. It can be said that providing non-judgmental feedback to the questions asked during the activities leads to the formation of these ideas in teacher candidates. As teacher candidates have stated, it is seen that critical thinking has positive contributions in learning, communication and cooperation among individuals facilitates the studies, and STEM education supports this by creating an environment where they can look at events from different angles (Honey, Pearson \& Schweingruber, 2014, p. 35). They stated that the learning environments should primarily be clean and spacious, the materials should be organized in order to find them easily, the necessary materials should be sufficient and the seating arrangement should be provided in order to communicate easily in the group work. The teacher candidates are able to express their thoughts, work in an orderly manner, etc. for 14 weeks in group work. It can be said that they have improved compared to their previous experiences. 
Evrekli et al. (2009) examined the opinions of pre-service science teachers about constructivist learning that they will apply when they start their profession. .The constructivist approach positively affects the active participation of students in the learning process, at the same time, with the constructivist approach, the teacher creates an environment where students can learn the learning environment in the best way by correcting the students' incomplete and incorrect information (Evrekli et al., 2009, p. 141). As a result of the study, it was stated that teacher candidates would be happy to use the constructivist approach in their classes in the future. In the studies of Pitsoe and Maila (2012), the constructivist learning effect on the professional development of teachers was examined. As a result, they stated that the constructivist learning model and STEM education are important for professional development, and specifically in classroom management and leadership, they have a positive effect on creating a better quality classroom environment and in teaching lessons more efficiently. When the quantitative analysis results in the sub-dimension related to real life are examined, a significant increase was observed in favor of the post-test. With constructivist learning, students are encouraged to think about it by presenting real-life information, and in this way, students can internalize information and transform it into their own knowledge, and produce solutions to problems using their knowledge (Duban, 2008, p. 91). In their study, Bolukbası Akbas and Gorgulu Ar1 (2021) stated that students adopt the knowledge they have acquired through STEM education in real life, increase their motivation and develop their creativity. In qualitative data, it was aimed to investigate to what extent they could associate the information they learned in the lessons with real life. According to the answers obtained from the pre-event interviews, the teacher candidates did not express an opinion about the relationship with real life because they did not know the content of the activity, while some students stated that they did not reconcile it with real life and did not think it had a relationship with real life, and that they were able to find solutions to the problems they face in daily life after the activity, that they grasped the working principles of electronic devices and that they were in the course of repair. They stated that they were able to use the information they learned and also provided permanent learning. At this point, it can be stated that it contributes to the use of the knowledge they have acquired in activities in daily life. As it is stated in constructivist learning, it is stated that STEM education can also guide individuals' communication with their peers in daily life and understanding the working principle of technological tools used by connecting the information they have learned in school to real life situations (Deghaidy \& Mansour, 2015, p. 52).

Considering the quantitative analysis results in the sub-dimensions of taking responsibility for learning and the role of the teacher, a significant increase was observed in favor of the posttest. According to the constructivist approach, the role of the teacher is to organize and manage the learning environment. In this process, the teacher acts as a guide and encourages the student to scientific knowledge and discussions. With the curiosity and effort of the learner, he takes responsibility for the information they learn (Qarareh, 2016, p. 193). According to Acar, 2020, it is stated that the teachers who will bring scientific and technological developments to the students in the 21st century should have received STEM education, and in this context, it is necessary to develop problem-solving skills in students and also teacher attitudes should contribute to the development of students' creative thinking skills. As a result of the study, it was stated that teachers had problem-solving skills, but there was no significant difference in the contribution of teacher behaviors to the development of creative thinking skills. In the

IBAD Sosyal Bilimler Dergisi / IBAD Journal of Social Sciences, (12), 2022 
analysis of qualitative data, while the teacher candidates made approximately the same expressions in their thoughts before and after the activity, the pre-service teachers stated that they became aware of their responsibilities after the activity, they were able to do their tasks in a planned manner in collaborative work, and that they acted consciously in the next activities with their experiences. In this case, it can be stated that pre-service teachers are provided with an active learning environment and opportunities to communicate effectively during the activities. In the qualitative analysis of the teacher role, which is also one of the subdimensions, they stated that the teacher candidates should act as a guide after giving information about the education, being patient in the face of the situations and being forwardlooking and guiding the possibilities, they stated that they should motivate the students with motivations. At this point, it can be said that the pre-service teachers' consciousness of taking responsibility for learning after the activity has developed and it has been ensured that they can apply the teacher role more effectively while performing their profession.

In STEM education, the distribution of tasks in the work done by individuals in collaboration with their peers and the individual fulfilling their duties by taking responsibility ensure that learning is effective and permanent, in this case, the trainer is in a passive position and guides the individuals when necessary (Deghaidy \& Mansour, 2015, p. 53). In the study of Gurkez (2021), it was stated that robotic coding education had a positive effect on academic achievement, metacognitive awareness and responsibilities for learning in secondary school students. When the quantitative analysis results were examined in the teaching processstrategy method technique sub-dimension, it was seen that there was a significant difference in favor of the post-test. In the constructivist learning environment, the individual chooses the appropriate strategy and method to be used in solving problems (Kroesbergen et al., 2015, p. 235). The learner's assumption with critical thinking skills leads to inferences and conclusions by interpreting the events and after discussing and evaluating them (Qarareh, 2016, p. 185). In a constructivist process, it is stated that learning is ensured by using the brainstorming strategy in situations where individuals make use of their previous knowledge, organize and select information (Maghsoudi \& Haririan, 2013, p. 61). In the analysis of qualitative data, pre-service teachers learn from contemporary education method techniques far from traditional teaching by discovery, be able to conduct research in the face of problems, not be accepted as it is, interpret the information critically, think and discuss the issues by brainstorming, and be free to express their opinions. They stated that effective learning will take place with collaborative learning environments at the time. It can be said that perceptions towards the characteristics of contemporary education understanding are created in the activities performed for teacher candidates, and this will enable teacher candidates to provide education that supports modern education in their professional lives.

With STEM education, the individual uses different methods and techniques to produce appropriate solutions to the problem (Kelley \& Knowles, 2016, p. 10). Integration of four disciplines with STEM supports constructivist learning in terms of being able to look at problem situations from all aspects and critically point of view, to work in collaboration with their peers by establishing effective communication with their peers, and to apply the knowledge they obtain in their daily lives as well as their academic life (Kennedy \& Odell, 2014, p. 254). In the studies of Karaman and Karaman (2016), the effect of the constructivist approach in the renewed science curricula (2013) has been examined by the opinions of science

IBAD Sosyal Bilimler Dergisi / IBAD Journal of Social Sciences, (12), 2022 
teachers. As a result of this study, the renewed curriculum of teachers, reducing the number of acquisitions, the subjects are distributed more balanced according to the class levels, and in this program based on the constructivist approach, the learning process based on activities and the learning process based on activities and the development of the students' high-level skills, as well as the process of measurement and evaluation. It was stated that its focus was welcomed by the teachers who participated in the study. They stated that the teacher's role as a guide during the education gave the students the opportunity to deal with their researches and activities patiently in this process, and they should ensure that they get information with guidance on issues they are stuck with. In his study, Qarareh (2016) investigated the effect of 8th grade students on their achievement and scientific thinking when the nature of light, mirrors, and lenses are processed using the constructivist learning model. As a result of this research, the constructivist learning model has a positive effect on student achievements, it has enabled the student to identify his / her strengths and weaknesses in learning, his active participation in the lesson, and to use the knowledge he / she learned in real situations. It has also been found to be an effective model for learning new subjects. The effect of the student on scientific thinking was observed that the constructivist learning model also had a positive effect on scientific process skills, as it was given the opportunity to apply thinking skills such as observation, explanation, classification, and conclusion, as well as developing hypotheses. Dharmadasa (2000) examined the views of teachers who used constructivist approach in their lessons in his study "Constructivist Teaching and Teachers' Perspectives on Learning". As a result of this study, it was stated that teachers' teaching by using a constructivist approach is fun, students are engaged in their own learning, and they allow students to use their experiences with active learning. Pre-service teachers stated that while applying STEM and STEM-based robotic activities to students in terms of contributing to their profession, they will increase permanence as they are provided with learning by doing and being active in the lesson.

Vihavainen et al. (2011) examined the thoughts of students who have just started programming teaching. The method used is continuous feedback and scanning improvement. The method has been applied in the CSI programming course and the rate of students dropping out of programming has decreased with the applied method compared to the previous methods. As a result of the research, he stated that learning by doing and living increases the motivation of the students. Balc1 (2007) examined the comparison of learning levels and attitudes towards science lesson of traditional teaching and constructivist teaching using subjects in the 8th grade genetics unit in his study. As a result of the study, it was stated that the comprehension levels and academic achievements of the students who receive education based on the constructivist approach are higher than the students who receive education based on the traditional approach. In addition, it was observed that the students who received education based on the constructivist approach enjoyed enduring the activities and found the lesson enjoyable. In this study, it was aimed to examine the physical, emotional and social effects of STEM activities and the constructivist approach on pre-service teachers. When the literature is examined, no parallel study has been found that examines the effects of STEM and STEM-based robotic coding activities on the views of constructivist learning environments in teacher candidates.

\section{SUGGESTIONS}

IBAD Sosyal Bilimler Dergisi / IBAD Journal of Social Sciences, (12), 2022 
This study was carried out with 4 th grade science teacher candidates of the education faculty of a state university. New studies to be carried out in line with this study can be carried out on different faculties and grade levels. In addition, applications can be made in schools together with secondary school science teachers after receiving their education for a certain period. This study was carried out for a total of 14 weeks, and the study can be worked for longer periods and the products obtained as a result of the study can be brought together within the scope of a project. It can be suggested that science teacher candidates should be trained as a compulsory course instead of covering the applications of STEM and STEM-based robotic activities developed by the researchers in a limited way within the scope of the elective course. In addition, one of the new programs, STEM education, should be given to teacher candidates starting from the 1st grade, so that they become competent educators who can apply this education program in their classes in accordance with the national education curriculum. In this way, it is to contribute to the training of high quality, active individuals for the future by ensuring the integration of teachers with STEM between the courses and the students realizing more efficient and contemporary learning in the classroom environment.

\section{REFERENCES}

Acar, D. (2020). The role of STEM awareness in predicting the contribution of teachers' problem solving skills and behaviors to the development of creative thinking. Academia Journal of Educational Research, 5(1), 77-89.

Alic1, M. (2018). The effect of STEM education on attitude, career perception and professional interest in a problem-based learning environment and students' opinions. Master Thesis, Kurıkkale University, Kırıkkale.

Aldridge, J.M. et al. (2004). Using teacher action research to promote constructivist learning environments in South Africa. South African Journal of Education, 24, 245-253.

Baki, A. \& Gokcek, T. (2012). An overview of mixed methods research. Electronic Journal of Social Sciences, 11(42), 1-21.

Balc1, A. S. (2007) The effect of constructivist approach in science teaching, Master Thesis, Selcuk University, Konya.

Bas, G. (2015) The effects of social-constructivist learning environment design on learners' academic achievement, attitudes towards the course and metacognitive awareness levels and their contributions to the learning process, PhD Thesis, Necmettin Erbakan University, Konya.

Bay, E. \& Karakaya, S. (2009). Evaluation of the effectiveness of constructivist curriculum applications in teacher education. Electronic Journal of Social Sciences, 8(28), 40-55.

Bektas, O. \& Aslan, F. (2019). Determining the opinions of pre-service science teachers about STEM applications. Maarif Schools International Journal of Educational Sciences, 3(2), 1750 . 
Bolukbası Akbas, G. \& Gorgulu Arı, G. (2021). STEM in terms of developing students' interest and thinking skills towards science: Teachers' opinions. Turkish Journal of Education, 6(1), 46-58.

Can, A. (2016). Quantitative data analysis in the scientific research process with SPSS. 6th Edition. Pegem Akademi.

Cobern, Wm. W. (1996). Constructivism and Non-Western science education research. International Journal of Science Education, 4(3), 287-302.

Creswell, J. W. (2017). Introduction to mixed methods research. (M. Sozbilir, trans. ed.). Pegem Academy.

Cakır, Z. et al. (2019). The effect of Montessori approach-based STEM activities on creativity skills of preschool teacher candidates. Journal of the International Scientific Research, 4(2), 392-409. https://doi.org/10.21733/ibad.548456

Cepni, S. (2017). STEM (+ A/+ E) education from theory to practice. Pegem Publishing.

Cevik, M. (2018). The effect of project-based (pjt) science, technology, engineering and mathematics (stem) education on academic achievement and professional interests of vocational high school students. Pegem Journal of Education and Training, 8(2), 281-306.

De Boer, G. (2000). Scientific literacy: another look at its historical and contemporary meanings and its relationship to science education reform. Journal of Research in Science Teaching, 37, 582-601.

Dharmadasa, I. (2000, April). Teachers' perspectives on constructivist teaching and learning. Paper presented at the Annual Conference and Exhibition of the Association for Childhood Education International. Baltimore, MD, April 17-20, 2000.

Duban, N. (2008). Analysing the elementary science and technology coursebook and student workbook in terms of constructivism. International Journal of Social, Behavioral, Educational, Economic, Business and Industrial Engineering, 2(2), 90-94.

Dugger, W. (2010). Evolution of STEM in the United States. In Technology Education Research Conference. Queensland.

El-Deghaidy, H. \& Mansour, N. (2015). Science teachers' perceptions of STEM education: Possibilities and challenges. International Journal of Learning and Teaching, 1(1), 51-54. https://doi.org/10.18178/ijlt.1.1.51-54

Ejiwale, J. (2013). Barriers to successful implementation of STEM education. Journal of Education and Learning, 7(2), 63-74.

Evrekli, E. et al. (2009). Examination of pre-service science teachers' attitudes towards the constructivist approach. Uludag University Journal of Education Faculty, 22(2), 673-687.

George, D. \& Mallery, M. (2010). SPSS for Windows Step by Step: A Simple Guide and Reference. 17.0 update (10a ed.). Pearson

Guldemir, S. \& Cinar, S. (2017). Science teachers and secondary school students' views on STEM activities. ULEAD 2017 Annual Congress, ICRE. 
Gurkez, S. (2021). The effect of secondary school students' robotic coding education on metacognitive skill awareness and learning responsibilities: The Example of Abilix Krypton 7. Master's thesis, Necmettin Erbakan University, Konya.

Guven, C., Selvi, M., \& Parlak, S. (2018). The effect of 7E learning model-centered stem activity-based teaching practices on academic achievement. Anemon Mus Alparslan University Journal of Social Sciences, 6, 73-80.

Hadjerrouit, S. (1998). A constructivist framework for integrating the Java paradigm into the undergraduate curriculum. SIGCSE Bulletin, 30(3), 105-107.

Honey, M. et al. (2014). STEM integration in K-12 education: Status, prospects, and an agenda for research. The National Academies Press. http://stemoregon.org/wpcontent/uploads/2014/04/STEM-Integration-in-K12Education-Book-Ginger-recommendation-fromOACTE.pdf. Accessed 1st January $\underline{2015}$.

Karaman, P. \& Karaman, A. (2016). Science teachers' views on the renewed science curriculum. Journal of Education Faculty, 18(1), 243-269.

Katz, L. (1999). Balancing constructivist and instructivist curriculum goals in early childhood education. In the kindergarten education: theory, research and practice. A Journal of the California Kindergarten Association, 4(2), 71-86.

Kaya, H. I. (2010) The effects of constructivist learning-based practices in teacher education on preservice teachers' problem solving, critical thinking and creative thinking tendencies. $\mathrm{PhD}$ Thesis, Ataturk University, Erzurum.

Kennedy, T. J., \& Odell, M. R. L. (2014). Engaging students in STEM education. Science Education International, 25(3), 246-258.

Kelley, T. R., \& Knowles, J. G. (2016). A conceptual framework for integrated STEM education. International Journal of STEM Education, 3(11).

Kroesbergen, E. H. et al. (2004). Effectiveness of explicit and constructivist mathematics instruction for low-achieving students in the Netherlands. Elementary School Journal, 104(3), 233-251.

Leask, M., \& Younie, S. 2001. Communal constructivist theory: Information and communications technology pedagogy and internationalisation of the curriculum. Journal of Information Technology for Teacher Education, 10, 117-134.

Maghsoudi, M., \& Haririan, J. (2013). The impact of brainstorming strategies Iranian EFL learners writing skill regarding their social class status. Journal of language and linguistics, 1(1), 60-67.

Miles, M. \& Huberman, M. (1984) Drawing valid meaning from qualitative data: Toward a shared craft. Educational Researcher, 13(5), 20-30.

Nunes, J.M. \& Mc Pherson, M.A. (2003) Constructivism vs. objectivism: Where is difference for designers of e-learning environments? Proceedings of the 3rd IEEE International Conference on Advanced Learning Technologies (ICALT'03), 496-500. 
Oner, A. T. et al. (2016). From STEM to STEAM: Students' beliefs about the use of their creativity the. STEAM Journal, 2(2), 1-14.

Ozdamar, K. (1999) Statistical data analysis with package programs. 1. Kaan Bookstore.

Pitsoe, V.J. \& Maila, W.M. 2012. Towards constructivist teacher professional development. Journal of Social Sciences, 8(3), 318-324.

Qarareh, A. O. (2016). The effect of using the constructivist learning model in teaching science on the achievement and scientific thinking of 8th grade students. International Education Studies, 9(7), 178.

Richardson, V. (1996). The role of attitudes and beliefs in learning to teach. In J. Sikula, T. Buttery, \& E. Guyton (Eds.). Handbook of research on teacher education. pp. 102-119. Simon \& Schuster Macmillan.

Seren, S. \& E. Veli (2018). Comparison of the inclusion levels of STEM education in the changed science curriculum as of 2005. Journal Of STEAM Education Science, Technology, Engineering, Mathematics and Art Education Journal, 1(1), 24-47.

Sasan, H. (2002). Constructivist learning', education as you live. 74-75, 49-52.

Thomas, T. A., (2014). Elementary teachers' receptivity to integrated science, technology, engineering, and mathematics (STEM) education in the elementary grades. Doctoral dissertation, University of Nevada, Reno.

Thomson, S. B. (2011). Qualitative research: Validity. JOAAG, 6(1), 77-82.

Topsakal, I., \& Altun Yalcın, S. (2020). Investigation of the effect of problem-based STEM education on students' learning climates. International Journal of Educational Researchers, 3(1), 42-59.

Vihavainen, A.et al. (2011). Extreme apprenticeship method in teaching programming for beginners. (pp. 93-98). Proceedings of the 42nd ACM technical symposium on Computer science education, SIGCSE '11, ACM.

Wicklein, R. C., \& Schell, J. W. (1995). Case studies of multidisciplinary approaches to integrating mathematics, science and technology education. Journal of Technology Education, 6(2), 1-9.

Xie, Y. et al. (2015). STEM education. Annual Review of Sociology, 41(41), 331-57.

Yildırım, B. \& Selvi M. (2017). An experimental study on STEM applications and the effects of mastery learning. Theory and Practice in Education, 13(2), 183-210. 